\title{
Agronomic Characteristics, Chemical Composition and In vitro Gas Production of Sugarcane Cultivars (Saccharum spp.) for Feeding Ruminants
}

\author{
Rafael Henrique Pereira dos Reis ${ }^{1}$, Joadil Gonçalves de Abreu ${ }^{2}$, \\ Roberto Giolo de Almeida ${ }^{3}$, Luciano da Silva Cabral ${ }^{2}$, Livia Vieira de Barros ${ }^{2}$, \\ Carlos Eduardo Avelino Cabral ${ }^{2}$, Arthur Behling Neto², Edegar Matter ${ }^{2 *}$, \\ Patricia Orlando Royer ${ }^{2}$, Dayenne Mariane Herrera ${ }^{2}$ \\ and Joana de Medeiros Farias ${ }^{2}$ \\ ${ }^{1}$ Federal Institute of Rondônia, Brazil. \\ ${ }^{2}$ Federal University of Mato Grosso, Cuiabá (MT), Brazil. \\ ${ }^{3}$ Brazilian Agricultural Research Corporation, Embrapa, Brazil.
}

\begin{abstract}
Authors' contributions
This work was carried out in collaboration among all authors. The authors JGA and LSC designed and wrote the protocol for the experiment. The authors RHPR and DMH conducted the experiment and wrote the first draft of the manuscript. The authors RGA, LVB, CEAC, ABN, EM, POR and JMF discussed the results, corrected and improved the writing of the manuscript in Portuguese and English versions. All authors read and approved the final manuscript.

Article Information

DOI: 10.9734/JEAI/2019/v35i130194

(1) Dr. Dalong Guo Professor, College of Forestry, Henan University of Science and Technology, Luoyang, People's Republic

Reviewers:

(1) Grace O. Tona, Ladoke Akintola University of Technology, Nigeria. (2) Mahmoud Abdelhamid Dawood, Kafrelsheikh University, Egypt. Complete Peer review History: http://www.sdiarticle3.com/review-history/48556
\end{abstract}

Original Research Article

Received 24 January 2019 Accepted 16 April 2019

Published 23 April 2019

\begin{abstract}
The aim of this work was to evaluate the agronomic characteristics, chemical composition and in vitro gas production of sugarcane (Saccharum spp.) cultivars used in ruminant feed. The experimental design was a randomized block containing seven treatments and three replications totaling 21 plots. The cultivars RB835436, RB925211, RB925345, RB937570, RB945961, RB955970 e SP91-1049 was evaluated for dry matter, dry matter yield, stalk percentage, stalk tons per hectare, plant height, stalk diameter, number of tillers per linear meter, mass per stem, soluble
\end{abstract}


solids content (BRIX), NDF/BRIX ratio and tons of sucrose/ha, total digestible nutrients, digestible energy, metabolizable energy, net energy and in vitro digestibility of organic matter, crude protein, neutral detergent fiber (NDF) and acid detergent, of digestion and In vitro gas production of nonfibrous carbohydrates, latency time, digestion rate and gas production of fibrous carbohydrates, and in vitro digestibility of organic matter. There was a significant difference between the cultivars regarding the neutral detergent fiber content, in vitro digestibility of organic matter, total digestible nutrients, digestible energy, net energy, degradation rates of fibrous and non-fibrous carbohydrates and latency period. There was a negative correlation between stem percentage and NDF/BRIX and positive correlation between in vitro digestibility of organic matter and total digestible nutrients. The results were submitted to analysis of variance and mean test by Scott-Knott and Pearson's correlation analysis. The statistical program used was SAEG 2000 . The RB835486 variety was superior to the other cultivars, as it presented $93.28 \%$ of stem, $57.5 \%$ of in vitro digestibility of organic matter, NDF / BRIX ratio of 2.68, 43.78\% NDF, latency period 2.86h and fibrous carbohydrate degradation rate of $2.26 \%$ per hour. Therefore, this cultivar was better indicated for animal feeding between May and July in the State of Mato Grosso, Brazil.

Keywords: Saccharum spp.; feeding ruminants; digestibility; in vitro degradation kinetics.

\section{INTRODUCTION}

Sugarcane forage is a bulky option for cattle, due to the high sucrose content coincident with the dry period of the year, high production of dry mass and energy per unit area. It presents a different characteristic of other forage grasses, since its nutritive value rises with the advancement of age, becoming an important bulk for use in ruminant feed mainly during the dry season [1].

Sugarcane is used as forage resource aiming to supplement the lack of forage during the dry season, when the nutrition of ruminants is impaired by the low quantity and quality of forages available for animal production systems in pasture. In addition to the high degradability sucrose in the rumen, sugarcane structural carbohydrates are a low-cost source of energy for animals in this system [2].

Despite being a food rich in high degradability of sucrose in the rumen, sugarcane presents low levels of crude protein and minerals as its mains limitations, besides high content of low ruminal degradation fiber [3]. This high fibre content reduces digestibility, and consequently decreases the dry matter intake by the animal.

NDF/Brix ratio proposed by Rodrigues et al. [4] and digestibility are fundamental characteristics in the selection of sugarcane cultivars for ruminant feeding since they take into account the fibre content in relation to the plant's sugar. Combining fibre content with digestibility, it is possible to select cultivars that can provide greater dry matter intake by animals.
The evaluation of the degradation kinetics of fibrous carbohydrates (FC) and non-fibrous carbohydrates (NFC) of sugarcane cultivars allows separating completely indigestible fractions, or those that reduce the availability of energy for microorganisms and are negatively correlated with dry matter intake. For sugarcane, the factors that basically determine its quality as ruminant feeding are the plant age and the genotype, and the former affects the nutritional value of plants due to architectural changes, ratio between leaves and stalks, and chemical composition of these fractions [5].

In this sense, this study aimed to evaluate early cultivars for the selection and use in ruminant feeding, considering the soil and climatic conditions of the State of Mato Grosso.

\section{MATERIALS AND METHODS}

The experiment was carried out at the Alcohol Distillery Libra, member of the Inter-University Network for the Development of Sugarcane Industry (RIDESA), in Sao José do Rio Claro-MT (lat. $13^{\circ} 45^{\prime} 33$ "S, long. 56 $36^{\prime} 41^{\prime \prime} \mathrm{W}$, at $350 \mathrm{~m}$ asl). According to the Koppen classification, the climate is Aw, rainy tropical, characterized by well-defined dry season between May and September. The soil was classified as Quartzarenic Neosol.

Rainfall during the experiment was $1,101 \mathrm{~mm}$; however, in the months of July and August, rainfall was zero. During the experiment, the annual mean temperature was $31.2^{\circ} \mathrm{C}$, with maximum of $37.5^{\circ} \mathrm{C}$ and minimum of $10.3^{\circ} \mathrm{C}$ observed in July. 
The experiment was established in an area that had been cultivated for three years and consisted of a complete randomized block design with seven treatments (cultivars), and three replications. Each plot consisted of five $8.0 \mathrm{~m}$ rows, spaced $1.3 \mathrm{~m}$, totaling $52 \mathrm{~m}^{2}$, and the three central rows were considered as useful area, discarding $0.5 \mathrm{~m}$ at the ends. The cultivars RB835486, RB925211, RB925345, RB937570, RB945961, RB955970 and SP91-1049 were evaluated in this experiment.

For the agronomic characteristics, five tillers were sampled from the useful area, where plant height $(\mathrm{PH})$ and stalk diameter at $30 \mathrm{~cm}$ from the ground (DIAM) were determined. Afterwards, tillers were cut close to the ground with the aid of an axe, to determine the matter per stalk (MPS) and percentage of stalks (PS). For the evaluation of tillering in plants re growth, the number of tillers per meter (NTM) was obtained by the mean of tillers counted on a linear meter in the useful area.

Dry matter yield (DMY) was obtained by multiplying the fresh matter yield $\left(\mathrm{t} \mathrm{ha}^{-1}\right)$ and the dry matter content. The value of tons of stalks per hectare (TSH) was obtained by multiplying the fresh matter yield by the percentage of stalks.

BRIX and POL values, which represent soluble solids and sucrose contents, respectively, in the fresh matter, were obtained by the methodology proposed by [6]. After that, the NDF/Brix ratio and tons of POL (TPH) per hectare were calculated, and the latter was obtained by multiplying the POL content by the fresh matter yield.

For the determination of the dry matter content (DM), tillers were crushed using a $2 \mathrm{~cm}$ stationary chopper. After chopping, the material was weighed, stored in paper bags, and were dried in forced-air ovens, at $55^{\circ} \mathrm{C}$ for 72 hours. Afterwards, the material was grounded through 2 $\mathrm{mm}$ sieves in a Willey mill. Then, crude protein (CP), ash and ether (EE) were determined [7]. For analysis of insoluble neutral detergent fiber (NDF) and insoluble acid detergent fiber (ADF), solutions described by Van Soest et al. [8] were used, and extraction in autoclave was carried out according to Pell and Schofield [9], using TNT bags (non-woven textile (NWT $100 \mathrm{~g} / \mathrm{m}^{2}$ ).

The technique of semi-automatic in vitro gas production was used to estimate in vitro organic matter digestibility (IVOMD), total digestible nutrients (TDN), digestible energy (DE), metabolizable energy (ME), and net energy (NE), according to the equations of Menke and Steingass [10]. The kinetics of cumulative production of gas was analyzed using the bicompartmental logistic model, as recommended by Schofield et al. [11].

Data was subjected to analysis of variance and Scott-Knott mean clustering test to $5 \%$ probability. Pearson's correlation analysis to 5\% probability was also carried out. The statistical program used was SAEG 2000.

\section{RESULTS AND DISCUSSION}

No significant difference was observed ( $p>.05)$ among cultivars in terms of dry matter content (DM), dry matter yield (DMY), percentage of stalk (PS), tons of stalks per hectare (TSH), stalk diameter (DIA), number of tillers per linear meter (NT), and mass per stalk (MPS). The means were $32.50 \%$; $29.89 \mathrm{t} \mathrm{ha}^{-1}$; 91,49\%; $84.14 \mathrm{tha}^{-1}$; $2.3 \mathrm{~cm} ; 11.18$ tillers $/ \mathrm{m} ; 0.97 \mathrm{~kg}$; respectively (Table 1).

Mean dry matter content was high at the beginning of the dry season, which can be observed when comparing with the means obtained by Freitas et al. [12] (24.40\%) for cultivars harvested in May, in the city of OratorioMG. The high DM values found in this study (mean of $32.5 \%$ ) can be explained by the sandy soil of the experimental area, which resulted in low water retention, and consequently in water loss by the culture at the beginning of the dry season.

Abreu et al. [13] obtained mean DMY of $10.14 \mathrm{t}$ DM ha ${ }^{-1}$ for the early cultivars IAC86- 2210, IAC86-2480, IAC93-6006, SP81-3250, IAC873396 and RB72454, in Red-Yellow Latosol, with harvest at 15 months after planting. The value found by these authors was much lower than that found in this study (29.89 $\left.\mathrm{t} \mathrm{DM} \mathrm{ha}^{-1}\right)$.

Rodrigues et al. [4] recommended PS above $80 \%$ for cultivars used to produce forage, since it does not hinder consumption by low ruminal degradation fiber intake. Although there was no significant difference, all cultivars responded to this premise.

The mean value obtained for TSH in a third clipping sugarcane field $\left(84.14 \mathrm{t} \mathrm{ha}^{-1}\right)$ was higher than that observed by Mello et al. [14], who found mean value of 57.81 and $91.23 \mathrm{t} \mathrm{ha}^{-1}$ for the third and first clippings, respectively. 
Cultivars differed in $\mathrm{PH}(\mathrm{p}<.05)$. Plant height is a characteristic associated with growth rate and is highly important for 12-month cycle genotypes [15]. PH was positively correlated with TSH $(r=0.80)$ and DMY $(r=0.78)$, which evidences the great importance of this characteristic on the productive aspects of cultivars. However, the high $\mathrm{PH}$ observed for cultivars RB925345 and RB937570 did not reflect increases in DMY, TSH, BRIX, and POL.

NT indicates greater potential for growth and closing lines [15], reducing the number of hoeing, which is interesting for the production system in order to reduce costs. Aside from cultivars RB925211 and RB925345, all the others presented NT lower than $12-13$ stalks/linear m, which is recommended by Landell et al. [16] for good establishment and continuity of a sugarcane field with forage purposes.
MPS depends on the density of plants per hectare and on the potential of cultivar tillering, and the plant will always maintain the balance between tiller number and size. No differences were found among cultivars for MPS, with means ranging from 0.92 to $1.15 \mathrm{~kg}$.

No significant difference $(p>0.05)$ was found among cultivars in relation to soluble solids (BRIX), sucrose (POL), crude protein (CP), acid detergent fiber (ADF), NDF/BRIX ratio, and tons of sucrose per hectare (TPH). Means were 16.86 $\mathrm{g} / 100 \mathrm{~g}$ juice; $14.77 \mathrm{~g} / 100 \mathrm{~g}$ juice; $1.39 \%$; $32.45 \% ; 2.82 ; 14.89 \mathrm{t} \mathrm{ha}^{-1}$, respectively (Table 2).

BRIX contents higher than $13 \%$ are considered acceptable to be used as sugarcane cultivar by the industry [13]. All cultivars showed BRIX values greater than $13 \%$, even though no significant difference was found among them.

Table 1. Dry matter content (DM), dry matter yield (DMY), percentage of stalk (PS), tons of stalks per hectare (TSH), plant height (PH), stalk diameter (DIA), number of tillers per meter (NT), and matter per stalk (MPS) of early sugarcane cultivars in Mato Grosso

\begin{tabular}{|c|c|c|c|c|c|c|c|c|}
\hline Cultivar & $\begin{array}{l}\text { DM } \\
(\%)\end{array}$ & $\begin{array}{l}\text { DRY } \\
\left(\mathrm{t} \mathrm{DM} \mathrm{ha}^{-1}\right)\end{array}$ & $\begin{array}{l}\text { PS } \\
(\%)\end{array}$ & $\begin{array}{l}\text { TSH } \\
\left(\mathrm{t} \mathrm{ha}^{-1}\right)\end{array}$ & $\begin{array}{l}\mathrm{PH}^{1} \\
\text { (m) }\end{array}$ & $\begin{array}{l}\text { DIA } \\
\text { (cm) }\end{array}$ & $\begin{array}{l}\text { NT } \\
\left(n^{\circ}\right)\end{array}$ & $\begin{array}{l}\text { MPS } \\
\text { (kg) }\end{array}$ \\
\hline RB835486 & 30.05 & 29.05 & 93.28 & 89.14 & $2.95 \mathrm{~B}$ & 2.27 & 11.44 & 1.00 \\
\hline RB925211 & 34.35 & 30.29 & 93.36 & 82.48 & $3.12 \mathrm{~B}$ & 2.08 & 12.88 & 0.84 \\
\hline RB925345 & 33.8 & 30.98 & 95.12 & 87.25 & $3.62 \mathrm{~A}$ & 2.27 & 12.33 & 0.92 \\
\hline RB937570 & 34.42 & 37.26 & 94.43 & 101.91 & $3.49 \mathrm{~A}$ & 2.55 & 11.55 & 1.15 \\
\hline RB945961 & 31.28 & 31.64 & 90.8 & 91.54 & $2.90 \mathrm{~B}$ & 2.37 & 10.88 & 1.09 \\
\hline RB955970 & 30.67 & 25.51 & 84.18 & 69.92 & $2.05 \mathrm{C}$ & 2.57 & 9.44 & 0.94 \\
\hline SP91-1049 & 33.1 & 21.8 & 89.82 & 72.98 & $2.44 \mathrm{C}$ & 2.02 & 10.11 & 0.92 \\
\hline Mean & 32.5 & 29.89 & 91.49 & 84.14 & 2.96 & 2.3 & 11.18 & 0.97 \\
\hline CV (\%) & 5.58 & 15.15 & 3.65 & 16.31 & 9.5 & 9.04 & 17.36 & 12.94 \\
\hline
\end{tabular}

Table 2. Soluble solids (BRIX), sucrose (POL), crude protein (CP), neutral detergent fiber (NDF) and acid detergent fibre (ADF), NDF/BRIX ratio and tons of sucrose/ha (TPH) for early sugarcane cultivars in Mato Grosso

\begin{tabular}{|c|c|c|c|c|c|c|c|}
\hline Cultivar & $\begin{array}{l}\text { BRIX } \\
\text { (g/100g } \\
\text { juice) }\end{array}$ & $\begin{array}{l}\mathrm{POL} \\
\text { (g/100g } \\
\text { juice) }\end{array}$ & $\begin{array}{l}\text { CP } \\
(\%)\end{array}$ & $\begin{array}{l}\text { NDF }^{1} \\
\text { (\%) }\end{array}$ & $\begin{array}{l}\text { ADF } \\
(\%)\end{array}$ & $\begin{array}{l}\text { NDF/BRIX } \\
-\end{array}$ & $\begin{array}{l}\text { TPH } \\
\left(\mathrm{t} \mathrm{ha}^{-1}\right)\end{array}$ \\
\hline RB835486 & 16.68 & 14.29 & 1.23 & $43.78 \mathrm{~B}$ & 32.26 & 2.68 & 16.38 \\
\hline RB925211 & 17.42 & 15.49 & 1.15 & $46.60 \mathrm{~B}$ & 32.76 & 2.75 & 13.15 \\
\hline RB925345 & 17.11 & 14.98 & 1.26 & $47.91 \mathrm{~B}$ & 34.66 & 2.8 & 15.18 \\
\hline RB937570 & 18.24 & 16.51 & 0.96 & $44.86 \mathrm{~B}$ & 30.6 & 2.48 & 19.28 \\
\hline RB945961 & 16.69 & 14.61 & 1.48 & $45.82 \mathrm{~B}$ & 31.05 & 2.64 & 16.6 \\
\hline RB955970 & 15.76 & 13.62 & 2.1 & $51.25 \mathrm{~A}$ & 32.45 & 3.13 & 12 \\
\hline SP91-1049 & 16.13 & 13.88 & 1.61 & $51.60 \mathrm{~A}$ & 33.86 & 3.24 & 12.5 \\
\hline Mean & 16.86 & 14.77 & 1.39 & 47.19 & 32.45 & 2.82 & 14.89 \\
\hline CV (\%) & 5.83 & 6.83 & 21.83 & 5.78 & 6.67 & 9.51 & 16.38 \\
\hline
\end{tabular}

${ }^{1}$ Means followed by different letters in the column statistically differ by the Scott-Knott test to 5\% probability 
Although the evaluation of BRIX is still useful, $\mathrm{POL}$ is a more efficient variable to indicate the sugar content in the juice. For this reason, it has been more frequently used by the sugar industry as an indicator of maturation. For Andrade [17], a sugarcane cultivar is considered mature when $\mathrm{POL}$ is greater than $14.4 \%$. Thus, from the animal nutrition point of view, POL is more appropriate measurement for the quantitation of non-fibrous carbohydrates, representing the high degradability carbohydrate in the rumen.

For [18] evaluated the influence of harvest time on second clipping cultivars and found variation in POL and TPH from $13.07 \%$ and $10.66 \mathrm{t} \mathrm{ha}^{-1}$ to $17.77 \%$ and $16.06 \mathrm{t} \mathrm{ha}^{-1}$ in early and late maturation cultivars, respectively. The values obtained by these authors for early cultivars are below the mean found for the cultivars of this study $(14.77 \%)$, and this response can be explained by the stressful condition that probably occurred in the experimental sites.

For a long time, the choice of cultivars for animal feeding was based on the high proportion of leaves in the total fresh matter [19], since the CP content in the leaf is higher than in the stalk. Since the stalk is the portion of greatest interest for animal feeding, CP content in sugarcane is not a selection criteria. The low CP content in sugarcane is intrinsic to forage; besides, breeding programs do not aim to increase it. In addition, low CP content can be corrected at a low cost, such as by adding urea and ammonium sulfate to the chopped cane [20].

The thickening of the cell wall, in detriment of cellular content, increases NDF, causing losses at qualitative level, and hinders the microbial attack in the rumen by decreasing the surface area. The lower rate of degradation and passage of fibrous food through the rumen decreases dry matter intake and energy [21].

RB955970 and SP91-1049 cultivars showed NDF contents higher than those of the other cultivars (51.25 and $51.60 \%$, respectively). These results corroborate those found by many researchers $[4,20,14,13]$ and [22], who observed mean NDF lower than 52\%. RB835486 cultivar presented similar response in the study carried out by Andrade et al. [23], who evaluated 60 genotypes at two clipping ages (early and intermediate) and found NDF of $45.07 \%$ for early clipping against $43.78 \%$ found in this study.
Similar to NDF, ADF content decreases with older sugarcane plants, due to the accumulation of carbohydrates in the plant. Also, it is common that early cultivars present higher ADF content than intermediate cultivars. ADF correlates negatively with the digestibility of the food, and therefore, cultivars with low ADF content should be used for animal feeding.

NDF/BRIX ratio takes into account the amount of energy consumed in relation to the low rumen degradation fiber content and is used as a parameter to prevent DM and energy intake by the animal from being limited by the high NDF rates. The values for this variable should be less than 2.7 for the cultivar to be suitable for ruminants feeding [4], and for that, cultivars with high PS should be selected, since this variable presented negative correlation with NDF/BRIX ( $r$ $=-0.69$ ).

RB835486, RB937570 and RB945961 cultivars presented NDF/Brix lower than 2.7 [4], and of these, only RB835486 had the greatest IVOMD and TDN (Table 3). Age influences the digestibility of sugarcane, since sucrose accumulation occurs during the dry season. The use of IVOMD as selection criteria is explained for this variable present positive correlation with the TDN content $(r=0.99)$, indicating the best cultivars to be used by animals.

This was observed by the TDN values of RB835486 and SP91-1049 cultivars of 57.56 and $58.24 \%$, respectively, which are higher values than those of the other cultivars and are in accordance with those observed by Azevedo et al. [24], of $55.8 \%$ for the early cultivar SP801842 , harvested at 426 days of age. The highest TDN values reflected in higher DE and ME values, and in greater mean values for RB 835486 and SP91-1049 cultivars. However, only the first cultivar showed highest NE (Table 3).

Nevertheless, the mean TDN content (54.99\%) observed for the early cultivars RB765418, RB855453, RB855336, SP80-1842 and SP811763 , on the first clipping, grown in Minas Gerais was lower than the value of $62.47 \%$ observed by [20] for the early cultivars RB765418, RB855453, RB855336, SP80-1842 and SP81-1763 $(62.47 \%)$, on the first clipping, grown in Minas Gerais. Higher TDN values may be due to the lower mean value of ADF found by these authors $(28.78 \%)$, when compared with the present study (32.45\%). 
The nutritional value of sugarcane is limited by the low cell wall digestion rate, which contributes to the low metabolizable energy to the animal and also reduces the efficiency of use of soluble sugars by the negative effect on ruminal ecosystem, due to low ruminal passage rate.

All characteristics related to rates of digestion of the fibrous and non-fibrous carbohydrate rates were different among cultivars (Table 4). Although RB835486 and SP91-1049 cultivars showed highest IVOMD and TDN, the former may result in lower limitation of DM intake and energy by the animals, since has a latency period of $2.86 \mathrm{~h}$, when compared with $3.74 \mathrm{~h}$ of the latter.

The time required for colonization and bacterial fixation to the substrate is called latency period. During this period, hydration of food particles, removal of inhibitory substances, and events related to effective adhesion and colonization of food particles by rumen microorganisms may occur.

The determination of the extent and of the nutrient degradation rate is important to estimate the energy supply to the microorganisms present in the rumen. While there is no difference between cultivars for POL content, cultivar RB937570 showed higher digesting ratefor nonfibrous carbohydrates (C1) $\left(0.68 \mathrm{~h}^{-1}\right)$. However, this cultivar had the highest latency period (3.42 h), together with the cultivar SP91-1049.

Cultivars RB835486, RB925211, RB925345, RB937570 and RB955970 formed a group with higher rates of degradation of fibrous carbohydrates (C2). Among the cultivars, RB835486 stood out for its high C2 value $\left(0.0226 \mathrm{~h}^{-1}\right)$, associated with higher values of IVOMD, TDN, DE and NE.

Table 3. Total digestible nutrients (TDN), digestible energy (DE), metabolizable energy (ME), net energy (NE) and in vitro organic matter digestibility (IVOMD) for early sugarcane cultivars

\begin{tabular}{llllll}
\hline Cultivar & $\begin{array}{l}\text { TDN }^{1} \\
(\%)\end{array}$ & $\begin{array}{l}\text { DE } \\
\text { Mcal/kg }\end{array}$ & $\begin{array}{l}\text { ME } \\
\text { Mcal/kg }\end{array}$ & $\begin{array}{l}\text { NE } \\
\text { Mcal/kg }\end{array}$ & $\begin{array}{l}\text { IVOMD } \\
\text { (\%) }\end{array}$ \\
\hline RB835486 & $57.6 \mathrm{~A}$ & $2.53 \mathrm{~A}$ & $2.08 \mathrm{~A}$ & $1.59 \mathrm{~A}$ & $57.56 \mathrm{~A}$ \\
RB925211 & $55.46 \mathrm{~B}$ & $2.44 \mathrm{~B}$ & $2.00 \mathrm{~B}$ & $1.50 \mathrm{~B}$ & $55.47 \mathrm{~B}$ \\
RB925345 & $52.11 \mathrm{C}$ & $2.29 \mathrm{C}$ & $1.88 \mathrm{C}$ & $1.46 \mathrm{C}$ & $52.13 \mathrm{C}$ \\
RB937570 & $54.99 \mathrm{~B}$ & $2.42 \mathrm{~B}$ & $1.98 \mathrm{~B}$ & $1.52 \mathrm{~B}$ & $55 \mathrm{~B}$ \\
RB945961 & $50.83 \mathrm{C}$ & $2.24 \mathrm{C}$ & $1.83 \mathrm{C}$ & $1.39 \mathrm{C}$ & $50.89 \mathrm{C}$ \\
RB955970 & $55.68 \mathrm{~B}$ & $2.45 \mathrm{~B}$ & $2.01 \mathrm{~B}$ & $1.62 \mathrm{~A}$ & $55.78 \mathrm{~B}$ \\
SP91-1049 & $58.23 \mathrm{~A}$ & $2.56 \mathrm{~A}$ & $2.10 \mathrm{~A}$ & $1.52 \mathrm{~B}$ & $58.24 \mathrm{~A}$ \\
Mean & 54.99 & 2.42 & 1.98 & 1.51 & 55.01 \\
CV (\%) & 2.96 & 2.96 & 2.96 & 3.92 & 2.92 \\
\hline
\end{tabular}

${ }^{1}$ Means followed by different letters in the column statistically differ by the Scott-Knott test to $5 \%$ probability

Table 4. Estimate of maximum gas volume of the NFC1 fraction (Vf1), digestion rate for the fraction of non-fibrous carbohydrates (C1), latency period (L), maximum gas volume of the FC2 fraction (Vf2) and digestion rate for the fraction of fibrous carbohydrates (C2) to determine the in vitro degradation kinetics of carbohydrates by the technique of gas production of early sugarcane cultivars in Mato Grosso

\begin{tabular}{lllllll}
\hline Cultivar & $\mathbf{V f}_{\mathbf{1}}$ & $\mathbf{C 1}$ & $\mathbf{L}^{\mathbf{1}}$ & $\mathbf{V f}_{\mathbf{2}}$ & $\mathbf{C 2}$ & $\mathbf{r}$ \\
\cline { 2 - 6 } & $\mathbf{( \mathbf { m L } )}$ & $\mathbf{( \mathbf { h } ^ { - 1 } )}$ & $\mathbf{( h )}$ & $\mathbf{( m L )}$ & $\left.\mathbf{( h}^{-1}\right)$ & \\
\hline RB835486 & $19.82 \mathrm{~B}$ & $0.35 \mathrm{C}$ & $2.86 \mathrm{~B}$ & $62.47 \mathrm{~B}$ & $0.0226 \mathrm{~A}$ & 0.99 \\
RB925211 & $16.72 \mathrm{C}$ & $0.39 \mathrm{C}$ & $3.00 \mathrm{~B}$ & $58.16 \mathrm{C}$ & $0.0229 \mathrm{~A}$ & 0.99 \\
RB925345 & $14.60 \mathrm{D}$ & $0.48 \mathrm{~B}$ & $2.98 \mathrm{~B}$ & $56.22 \mathrm{C}$ & $0.0234 \mathrm{~A}$ & 0.99 \\
RB937570 & $18.36 \mathrm{~B}$ & $0.68 \mathrm{~A}$ & $3.42 \mathrm{~A}$ & $58.15 \mathrm{C}$ & $0.0224 \mathrm{~A}$ & 0.99 \\
RB945961 & $16.27 \mathrm{C}$ & $0.40 \mathrm{C}$ & $2.88 \mathrm{~B}$ & $52.81 \mathrm{D}$ & $0.0218 \mathrm{~B}$ & 0.99 \\
RB955970 & $13.67 \mathrm{D}$ & $0.30 \mathrm{C}$ & $2.69 \mathrm{~B}$ & $68.08 \mathrm{~A}$ & $0.0224 \mathrm{~A}$ & 0.99 \\
SP91-1049 & $21.89 \mathrm{~A}$ & $0.53 \mathrm{~B}$ & $3.74 \mathrm{~A}$ & $59.30 \mathrm{C}$ & $0.0212 \mathrm{~B}$ & 0.99 \\
Mean & 17.33 & 0.45 & 3.08 & 59.31 & 0.0224 & 0.99 \\
CV (\%) & 6.92 & 23.89 & 11.85 & 5.21 & 2.86 & 0.35 \\
\hline
\end{tabular}

\footnotetext{
Means followed by different letters in the column statistically differ by the Scott-Knott test to 5\% probability
} 
In this work, since the cultivars did not differ in relation to production variables, NDF, IVOMD, TDN, DE, NE, rates of degradation of fibrous and non-fibrous carbohydrates, and latency period were taken as crucial characteristics in selection of cultivars. Selection criteria are more related to the nutritional value, since evaluation of voluntary feed intake are not carried out with animals.

\section{CONCLUSIONS}

Cultivars present different rates of neutral detergent fiber, in vitro organic matter digestibility, total digestible nutrients and digestible energy values, net energy, rates of degradation of fibrous and non-fibrous carbohydrates, and latency period. Cultivar RB835486 is the most suitable for ruminant feeding between May and July for the state of Mato Grosso.

\section{COMPETING INTERESTS}

Authors have declared that no competing interests exist.

\section{REFERENCES}

1. Silveira RN, Berchielli TT, Canesin RC, Messana DJ, Resi RA, Resende KT. Effects of nitrogen sources in the intake, total and partial digestibility of steers feeding on sugarcane. Acta Scientia Animal Sciences. 2009;31(3):279-285.

2. Oliveira MDS. Sugarcane in cattle feeding. Jaboticabal: FUNEP; 1999. Portuguese.

3. Moraes KAK, Valadares Filho SC, Moraes EHBK, Leão MI, Valadares RFD, Detmann $E$, et al. Sugarcane treated with calcium oxide and different concentrate levels for feedlot beef heifers. Brazilian Journal of Animal Science. 2008;37(7):1301-1310. Portuguese.

4. Rodrigues AA, Primavesi O, Esteves SN. Effect of sugar cane varieties quality on its value as cattle feed. Brazilian Journal of Agricultural Research.1997;32(12):13331338. Portuguese.

5. Rodrigues AA, Esteves SN. Sugarcane and urea for feeding cattle in the dry season. São Carlos: Embrapa Livestock Southeast; 1992. Portuguese.

6. COOPERSUCAR - Central Cooperative of Sugar and Alcohol Producers of São Paulo state. Sampling and analysis of sugarcane. Piracicaba: CTC; 1980. Portuguese.
7. AOAC - Association of Official Agricultural Chemists. Official methods of analysis of the association of official analytical chemists. Washington: USDA; 1975.

8. Van Soest PJ, Robertson JB, Lewis BA. Methods for dietary fiber, neutral detergent fiber, and no starch polysaccharides in relation to animal nutrition. Journal of Dairy Science.1991;74(10):3583-3597.

9. Pell AN, Schofield P. Computerized monitoring of gas production to measure forage digestion in vitro. Journal of Dairy Science. 1993;76(9):1063-1073.

10. Menke $\mathrm{KH}$, Steingass $\mathrm{H}$. Estimation of the energetic feed value obtained from chemical analysis and gas production using rumen fluid. Animal Research Development. 1988;28:7-55.

11. Schofield P, Pitt RE, Pell NA. Cinetics of fiber digestion from in vitro gas production. Journal of Animal Science. 1994;72(11): 2980-2991.

12. Freitas AWP, Pereira JC, Rocha FC, Detmann E, Barbosa MHP, Ribeiro MD, et al. Evaluation of the nutritional divergence of sugarcane (Saccharum spp.) genotypes. Brazilian Journal of Animal Science. 2006; 35(1):229-236. Portuguese.

13. Abreu JBR, Almeida JCC, Mello WA, Pereira VV, Ferreira MCM, Marques RAFS, et al. Production, morphological traits and ripeness characteristics of sugar cane cultivars with different maturity cycle at Barbacena region/ MG, Brazil. Animal Industry Bulletin. 2007;64(2):115-121. Portuguese.

14. Mello SQS, France AFS, Lima MLM, Ribeiro DS, Miyagi ES, Reis JG. Parameters for nutritive value of nine sugarcane varieties cultivated under irrigation. Brazilian Animal Science. 2006; 7(4):373-380. Portuguese.

15. Silva MA, Landell MGA, Campana MP, Zimback L. Competition of sugarcane genotypes under conditions of cane planting of year, in a dark red Oxisol eutrophic of the region of Jaú (SP). In: National Congress of the Sugar and Alcohol Technicians Society of Brazil. Londrina, STAB; 1999. Portuguese.

16. Landell MGA, Campana MP, Rodrigues AA, Cruz GM, Batista LAR, Figueiredo $P$, et al. The cultivar IAC86-2480: new option for sugar cane for forage purposes: management of production and use in animal feeding. Campinas: IAC; 2002. Portuguese. 
17. Andrade LAB. Culture of sugarcane. In: Cardoso MG. Production of sugarcane brandy. Lavras: UFLA; 2006. Portuguese.

18. Silva MA, Jerônimo EM, Lucio AD. Height of cut and harvest period effects on tillering and yield of sugarcane. Brazilian Journal of Agricultural Research. 2008;43(8):979986. Portuguese.

19. Boin C, Mattos WRS, D'arce RD. Sugarcane and its by-products in feed for ruminants. In: Paranhos, SB Sugarcane, cultivation and utilization. Cargill Foundation, Campinas; 1987. Portuguese.

20. Fernandes AM, Queiroz AC, Pereira JC, Lana RP, Barbosa MHP, Fonseca DM, et al. Chemical composition of sugar cane varieties (Saccharum spp I.) with different cycles of production in three cut time. Brazilian Journal of Animal Science. 2003; 32(4):977-985. Portuguese.
21. Van Soest PJ. Nutritional ecology of the ruminant. Comstock, Ithaca; 1994.

22. Bonomo P, Cardoso CMM, Pedreira MS, Santos CC, Pires AJV, Silva FF. Forage potential of sugarcane varieties for ruminant feeding. Acta Scientiarum Animal Sciences. 2009;31(1):53-59. Portuguese

23. Andrade JB, Ferrari Junior E, Possenti R, Otsuk IP, Zimback L, Landell MGA. Chemical composition of sugarcane in two ages, for animal nutrition. Bragantia. 2004; 63(3):341-349. Portuguese.

24. Azevedo JAC, Pereira JC, Queiroz ACE, Carneiro PCS, Lana RP, Barbosa MHP, et al. Chemical-Bromatological composition, fractionation of carbohydrates and in vitro fiber degradation kinetics of three sugarcane (Saccharum spp.) varieties. Brazilian Journal of Animal Science. 2003; 32(6):1443-1453. Portuguese.

(c) 2019 Reis et al.; This is an Open Access article distributed under the terms of the Creative Commons Attribution License (http://creativecommons.org/licenses/by/4.0), which permits unrestricted use, distribution, and reproduction in any medium, provided the original work is properly cited.

Peer-review history:

The peer review history for this paper can be accessed here: http://www.sdiarticle3.com/review-history/48556 